\title{
Practical measures for reducing risk of alfalfa bloat in cattle
}

\author{
WALTER MAJAK, JOHN W. HALL AND TIM A. MCALLISTER
}

Authors are toxic plant biochemist, biostatistician and rumen microbiologist, Agriculture \& Agri-Food Canada, Range Research Unit, Kamloops, B.C. V2B 8A9; Research Centre, Summerland, B.C. VOH 1ZO; and Research Centre, Lethbridge, AB. T1J 4 B1.

\begin{abstract}
Frothy bloat in cattle is a serious problem and is difficult to manage under field conditions as it progresses rapidly from early signs of distension to acute distress. Scientists at Agriculture and Agri-Food Canada centres in Western Canada are committed to the development of bloat-free alfalfa grazing systems, which may require feed additives or supplements. As well, a new cultivar of alfalfa (AC Grazeland), selected for a low initial rate of digestion, will soon be available. In grazing trials the cultivar reduced the incidence of bloat by an average of $56 \%$ compared with the control cultivar (Beaver). Commonly accepted mineral mixes for the prevention of bloat were tested and found ineffective but we have confirmed that poloxalene (Bloatguard $®$ ) is $100 \%$ effective if it is given intraruminally at the prescribed dose. However, under practical conditions, poloxalene can only be offered free choice and protection from bloat cannot be guaranteed. We have also shown that the water soluble polymer, Blocare ${ }^{\circledR} 4511$, when used in the water supply is $\mathbf{1 0 0 \%}$ effective in bloat prevention. This product is not yet registered in North America. Other strategies for bloat prevention will be discussed, including the selection of growth stages and grazing schedules, and the reduction of risk by wilting alfalfa or combining it with tannin-containing forages.
\end{abstract}

Key Words: pasture management, frothy bloat, legumes, feed additives

The incidence of frothy bloat in cattle increases worldwide as legume forages gain popularity in cultivated pastures and, more recently, in land reclamation. In North America, alfalfa (Medicago sativa L.) is the predominant legume forage and is favoured for its high yield, nutritional quality and winter hardiness. The economic benefits of alfalfa in grazing systems for cattle are not fully realized because of the risk of frothy bloat. This digestive disorder is difficult to manage under field conditions as it progresses rapidly and unpredictably from early signs of discomfort and distension to acute distress and pronounced swelling of the left flank. The inability to expel fermentation gases and the resultant formation of a stable foam in the rumen can have fatal consequences.

Bloat research with ruminally fistulated cattle at Kamloops, B.C. and more recently at Lethbridge, $A B$ has been designed to better understand the plant, animal and microbial factors involved in the etiology of bloat. Feeding regimens in both pens and pastures have been developed to express bloat in cattle reliably and reproducibly thereby permitting evaluation of chemical, biologi-

Manuscript accepted 27 Nov. 00.

\section{Resumen}

El timpanismo espumoso es un problema serio en ganado y es difícil de manejar bajo las condiciones de campo conforme progresa rápidamente de los signos iniciales de distensión aguda. Científicos en los centros Agricultre and Agri-Food Canada del oeste de Canadá estan comprometidos al desarrollo de sistemas de apacentamiento de alfalfa libres de timpanismo, los cuales pueden requerir alimentos aditivos o suplementos. También un nuevo cultivar (AC Grazeland), seleccionado para una tasa inicial baja de digestión pronto estará disponible. En ensayos de apacentamiento el cultivar redujo la incidencia de timpanismo en promedio de $62 \%$ comparado con el cultivar control (Beaver). Se probaron mezclas minerales comúnmente aceptadas para evitar timpanismo y se encontró que fueron inefectivas, pero hemos confirmado que el Poloxeno (Bloatguard ${ }^{\circledR}$ ) es $100 \%$ efectivo si es administrado intraruminalmente a la dosis recomendada. Sin embargo, bajo las condiciones practicas el poloxeno puede ser solo ofrecido a libre acceso y la protección contra timpanismo no puede ser garantizada. Tambiém hemos mostrado que cuando el polímero soluble en agua Blocare ® 4511 se utiliza en el suministro de agua es $100 \%$ efectivo para evitar el timpanismo. Este producto aun no es registrado en Norte América. Otras estrategias para evitar el timpanismo serán discutidas, incluyendo la selección de etapas de estados de crecimiento y calendarios de apacentamiento y la reducción del riesgo mediante el marchitamiento de la alfalfa o combinandola con forrajes que contienen taninos.

cal and climatic variables involved in bloat. Feed additives for the control and prevention of bloat have also been tested. This paper will summarize research results on bloat in Western Canada with a view of providing practical information on pasture management. It will also report on recent bloat trials with cattle that yielded further strategies for reducing the risk of alfalfa bloat.

\section{Materials and Methods}

Each trial was conducted with 2 to 4 groups of ruminally fistulated Jersey steers, 7 to 10 years old. There were 3 to 5 animals per group, with 4 animals per group used in most studies. Studies were conducted either in confinement, where animals were fed freshly harvested alfalfa cut daily at 0700 hours $\left(58 \mathrm{~kg} \mathrm{head}^{-1}\right.$, fresh weight), or in alfalfa pastures under grazing conditions. The alfalfa, which was irrigated, was cut with a flail-type harvester (New Holland, Crop-Chopper ${ }^{\circledR}$ Forage Harvester 38). Except for the stage of growth studies, the alfalfa was usually at the vegetative to early bud stage. The average crude protein and acid deter- 
gent fibre contents were $21.4 \pm 0.49$ and $29.1 \pm 0.81 \%(n=79)$, respectively, on a dry matter basis. Studies were conducted during the summer growing season and in the fall at Kamloops, B.C. (lat. 50 $42^{\prime} \mathrm{N}$, long. $\left.120^{\circ} 27^{\prime} \mathrm{W}\right)$. Animals were cared for under the guidelines of the Canadian Council on Animal Care. An animal was classified as bloated if it showed 1) visible distension of one or both flanks prior to removing the cannula plug and 2) release of internal pressure and ejection of a stream of frothy ruminal contents after plug removal. This event could occur within 1 hour of feeding in confinement or within 2 hours of grazing on the pasture.

Each trial was designed as a crossover experiment in which animal groups were switched after each test period to determine the effect of the treatment on all animals on test. In these trials, the length of each test period was not specified but was determined by the total number of cases of bloat observed. A single animal bloating on 1 day was counted as 1 case but the animal may have distended more than once on that day. A minimum of 24 cases of bloat per crossover period provided reasonable power for detecting treatment differences. All of the steers were susceptible to bloat as determined in previous trials but none were chronic bloaters. Statistical comparisons of the effects of treatments took into account the daily fluctuations in the bloat potential of the alfalfa, which affected the susceptibility of each animal on test (Majak et al. 1995). A significance level of 0.05 was used throughout to compare treatment effects.

\section{Results and Discussion}

\section{Stage of Growth}

It has long been accepted that the probability of legume bloat decreases with advancing stages of plant maturity. The decrease has been mainly attributed to a decrease in the soluble protein content of the legume (Majak et al. 1995). Alfalfa proteins can contribute to the frothiness of rumen contents (Howarth et al. 1986). The effect of plant maturity on the incidence of frothy bloat in cattle was examined in feeding trials. Alfalfa at the vegetative, bud and bloom stages of growth was simultaneously harvested and fed to 3 groups of cattle in a 3-way crossover experiment (Thompson et al. 2000). The vegetative stage yielded the highest incidence of bloat as compared with the bud or bloom stage. The bloom stage had no cases of bloat. These results indicate the potential for grazing management through selection of plant phenology as a method of bloat control. In practice, it would be essential to recognize the predominant stage of growth of the stand before turning out cattle to pasture. The leaf to stem ratio should also be recognized as a factor in bloat throughout all stages of growth (Thompson et al. 2000). An exceptional leafy bloom stage can also cause bloat (W. Majak, unpublished results).

\section{AC Grazeland}

The quest for a cultivar of alfalfa that was bloat-free began over 30 years ago when attempts were made to select an alfalfa strain with a low soluble protein content (Majak et al. 1995). Subsequently, extensive studies were conducted comparing legumes that do and those that do not cause bloat in order to elucidate the chemical and morphological features that distinguish the 2 types of species (Goplen et al. 1993). The net result of the investigation suggested that an alfalfa with a lower potential for bloat might be produced by reducing its initial rate of digestion (IRD). Selection for this trait was feasible using a modified nylon bag technique. The low IRD was mainly expressed at earlier stages of growth, when the potential for bloat was highest (Goplen et al. 1993, Berg et al. 1995). Low IRD selections were tested in grazing trials at Lethbridge and Kamloops. The resulting new alfalfa cultivar (AC Grazeland) reduced the incidence of bloat by an average of $56 \%$ compared with the control cultivar Beaver (Berg et al. 2000). As well, these initial studies suggested that the severity of bloat was reduced as indicated by the reduction in multiple distensions of the rumen with AC Grazeland (Majak et al. 1999).

The efficacy of AC Grazeland in the reduction of bloat could be further enhanced with the use of the ionophore monensin given intraruminally as a controlled release capsule (Rumensin CRC ${ }^{\circledR}$ ). On average, a $50 \%$ reduction in bloat was obtained if the bolus was used in combination with AC Grazeland (Hall et al. 2001). The bolus reduced bloat by $50 \%$ in earlier trials with unspecified cultivars of alfalfa at unspecified stages of growth (Merrill and Stobbs 1993).

\section{Feed Additives}

In response to producers' inquiries and demands over the last decade, we have tested, under experimental conditions, a number of feed additives and supplements reputed to be effective in the prevention of pasture bloat. It should be noted that these tests were conducted under confinement conditions. Our experience suggests that unlike continuous grazing conditions, harvesting and feeding fresh herbage daily in confinement is a much more vigorous and reliable test of the efficacy of a treatment owing to the higher incidence of bloat that is generated (Majak et al. 1995). In a crossover experiment at Kamloops during 1999 , more bloat $(\mathrm{P}<0.05)$ occurred in confinement (30 cases) than during continuous grazing (21 cases).

As reviewed by Majak et al. (1995), numerous theories on the use of mineral supplements, household detergents and flocculants were tested for the prevention of alfalfa bloat and most were found to be ineffective. The surfactant poloxalene (Bloat Guard ${ }^{\circledR}$ ) was $100 \%$ effective if given intraruminally at the prescribed dose even under severe bloat challenge. The major difficulty is that it is expensive and must be fed daily with a feed supplement, or with a salt or mineral mix. Protection from bloat cannot be guaranteed with poloxalene or other insoluble anti-bloat agents because they are given free choice and animal intake is highly variable. A more effective approach for administering anti-bloat agents to grazing cattle would be to administer them through the water supply. This would provide a uniform intake and rapid dispersal of the agent throughout the rumen. Such water-soluble products are available in New Zealand and Australia but they are not registered in North America. One such agent, Blocare ${ }^{\circledR}$ 4511, was recently tested at Kamloops under severe bloat challenge using 2 groups of 4 steers in a crossover design. The soluble agent was administered at $0.1 \%$ in the water supply. As shown in Table 1, Blocare ${ }^{\circledR} 4511$ was $100 \%$ effec-

Table 1. Effect of Blocare ${ }^{\circledR} 4511$ treatment on the incidence of bloat in cattle fed alfalfa herbage during 1995.

\begin{tabular}{|c|c|c|}
\hline \multirow[b]{2}{*}{ Cross-over period } & \multicolumn{2}{|c|}{ Treatment $^{1}$} \\
\hline & Control & Blocare $^{(\mathrm{B})} 4511$ \\
\hline & \multicolumn{2}{|c|}{ - - (Number of bloat cases) - - } \\
\hline 29 June-23 July & 24 & 0 \\
\hline 27 July-5 August & 24 & 0 \\
\hline Total $^{2}$ & 48 & 0 \\
\hline
\end{tabular}

tive in the prevention of alfalfa bloat, even under conditions of severe bloat where many cases were designated at a rating of 4 on a scale of 1 to 5 (Majak et al. 1995). 
It is generally accepted that high-molecular weight synthetic polymers such as poloxalene and Blocare ${ }^{\circledR} 4511$ are nontoxic at the recommended formulations and that they are excreted intact from the ruminant digestive system. Recently the complete efficacy of Blocare ${ }^{\circledR} 4511$ was substantiated in alfalfa grazing trials at 3 locations in Western Canada (Stanford et al. 2001). Clearly this product has the potential to protect livestock from alfalfa bloat and its registration in North America should be promoted.

\section{Diet Manipulation}

Non-bloating legumes such as sainfoin (Onobrychis viciifolia Scop.) have endogenous chemical and morphological features that render them digestible in the rumen without causing the rapid fermentation and excessive gas production conducive to foam formation. Sainfoin contains high levels of condensed tannins, polyphenolic polymers that can interact with feed, microbial and plant proteins. Unlike alfalfa, legumes that have high levels of condensed tannins are bloat-free due, in part to the protein binding capacity of the endogenous tannins. In recent studies, fresh alfalfa was fed alone or with sainfoin herbage (at 10 to $20 \%$ on a dry matter basis) to determine the impact of sainfoin tannins on the occurrence of alfalfa bloat. Sainfoin supplements were also given as hay or pellets. The crossover experiment utilized 2 groups of 4 steers during 1994 to 1997 . Including sainfoin in the diet reduced $(\mathrm{P}<0.001)$ the incidence of bloat by 45 to $93 \%$ in 3 of the 4 years irrespective of the form in which sainfoin was supplied (McMahon et al. 1999). The variation in the response to sainfoin supplements could be partly attributed to the chemistry of sainfoin tannin polymers, which show considerable variation with stage of leaf development (Koupai-Abyazani et al. 1993). Nevertheless, there is potential for reducing bloat by cultivation of pastures containing mixtures of alfalfa and sainfoin or other bloat-free legumes.

In contrast to condensed tannins, which can depress the incidence of alfalfa bloat, other feed supplements have the capacity to increase the risk of bloat. The escalation is usually caused by an excessive release and availability of nutrients in the rumen with a resultant burst of microbial fermentation and gas production. Where bloat problems are encountered and the diet contains rapidly fermentable feedstuffs, such as beet pulp or molasses, the removal of these components from the diet is often sufficient to control bloat. Molasses is

Table 2. Effect of barley or molasses top dressing on the incidence of bloat in cattle fed alfalfa herbage during 1996.

\begin{tabular}{|c|c|c|c|}
\hline \multirow[b]{2}{*}{ Cross-over period } & \multicolumn{3}{|c|}{ Treatment $^{1}$} \\
\hline & Control & Barley & Molasses \\
\hline & \multicolumn{3}{|c|}{ 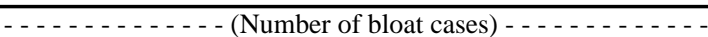 } \\
\hline 13-18 June & 8 & 12 & 13 \\
\hline 20-24 June & 9 & 10 & 14 \\
\hline 1-11 July & 6 & 0 & 25 \\
\hline Total $^{2}$ & 23 & 22 & 52 \\
\hline
\end{tabular}

${ }^{1}$ Three groups of 4 cattle were fed fresh alfalfa daily, with or without a top dressing of barley $\left(2.72 \mathrm{~kg} \mathrm{head}^{-1}\right)$ or molasses $\left(1.36 \mathrm{~kg} \mathrm{head}^{-1}\right)$.

${ }^{2} \mathrm{P}<0.01$ (molasses)

composed of approximately 50\% glucose and fructose (Harris et al. 1981) and these simple invert sugars are highly fermentable. A study was conducted in 1996 to compare the effects of 2 supplementary carbohydrate sources on the occurrence of alfalfa bloat in cattle (Table 2). More than twice as many cases of bloat occurred with molasses supplements $(\mathrm{P}<0.01)$ than with barley, which was not significantly different from the control. The energy source in barley is starch, which ferments at a slower rate.

\section{Swathing and Wilting}

It is clear that alfalfa leaf proteins are intimately involved in the onset of bloat. A significant decrease in the frequency of bloat can occur if the alfalfa protein chemistry is modified through complex formation with tannins or during senescence.

Table 3. Effect of swathing and wilting alfalfa on the incidence of bloat in cattle fed alfalfa herbage during 1994, 1997, and 1999.

\begin{tabular}{|c|c|c|c|}
\hline \multirow[b]{2}{*}{ Cross-over period } & \multicolumn{3}{|c|}{ Treatment $^{1}$} \\
\hline & Control & Wilted 24 hours & Wilted 48 hours \\
\hline & $-\cdots-\cdots$ & Number of bloat ca & - - - - - - - \\
\hline \multicolumn{4}{|c|}{ 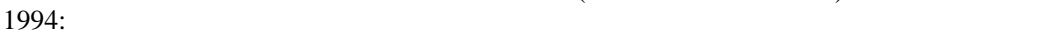 } \\
\hline 18-23 Aug & 19 & 8 & --- \\
\hline 25 Aug-7 Sept & 22 & 10 & --- \\
\hline Total $^{2}$ & 41 & 18 & --- \\
\hline 4-7 Sept & 19 & --- & 8 \\
\hline 9-13 Sept & 8 & --- & 1 \\
\hline Total $^{3}$ & 27 & --- & 9 \\
\hline \multicolumn{4}{|l|}{ 1997: } \\
\hline 5-16 Aug & 19 & 8 & 0 \\
\hline 17-29 Aug & 14 & 14 & 0 \\
\hline 30 Aug-3 Sept & 14 & 13 & 0 \\
\hline Total $^{4}$ & 47 & 35 & 0 \\
\hline \multicolumn{4}{|l|}{ 1999: } \\
\hline 19-30 Aug & $19(81)^{6}$ & --- & $0(50)^{7}$ \\
\hline 31 Aug- 5 Sept & $17(82)$ & --- & $6(59)$ \\
\hline Total $^{5}$ & 36 & --- & 6 \\
\hline
\end{tabular}

${ }^{1}$ Two groups of 5 cattle in 1994, 3 groups of 4 in 1997, and 2 groups of 4 in 1999 were fed a fresh swath of alfalfa (WL 225 ) or a swath that was wilted 24 or 48 hours.

${ }^{2} \mathrm{P}<0.01$.

${ }^{3} \mathrm{P}<0.01$.

${ }^{4} \mathrm{P}<0.05$ (24 hours), $\mathrm{P}<0.01$ (48 hours)

${ }^{5} \mathrm{P}<0.01$.

${ }^{6,7}$ Average moisture content $(\%)$ in alfalfa herbage. ${ }^{6} \mathrm{SE}=1.2,{ }^{7} \mathrm{SE}=8.2$ 
alfalfa bloat in each year of the study (Table 3). The reduction was greater $(\mathrm{P}<$ 0.01 ) if the alfalfa was wilted for 48 hours and in 1997 bloat was eliminated after a 48 hour wilt. The difference between years in the response to the 48 hour treatment could be attributed to the swathing dates of the alfalfa. In 1994, the swaths were cut later in the season and the morning dew may have impeded wilting. A similar trend was observed in 1999. The moisture content of the wilted swath was lower in the first part of the crossover experiment when bloat was eliminated after a 48 hour wilt (Table 3). The results for 1999 suggest that a $30 \%$ reduction in moisture during wilting may be sufficient to eliminate the risk of bloat. Grazing alfalfa pastures that have been swathed and wilted provides yet another strategy for reducing the risk of bloat.

\section{Climate}

It is obvious that the growing conditions of the alfalfa can affect the protein content of the plant and the content of other plant constituents that may contribute to the onset of bloat. At Kamloops, alfalfa is grown under irrigation and the impact of seasonal rainfall patterns on the incidence of bloat cannot be assessed. Other climatic variables were screened at Kamloops but none were found to be useful indicators or predictors of the occurrence of bloat (Hall et al. 1984). The commonly held opinion that alfalfa is bloat-safe after a killing frost was also refuted (Hall and Majak 1991). More recently in Kamloops, an atypical cool, wet spring was associated with an extremely high incidence of bloat (Hall et al. 2001).

\section{Feeding Regimens}

Lastly, the feeding habits of the grazer need to be considered to further understand the etiology of alfalfa bloat. It is well established that feeding regimens that are continuous and uninterrupted are less likely to cause bloat (Majak et al. 1995). The key is to promote continuous and rapid turnover of the rumen and to prevent distortions of the natural processes of microbial fermentation that increase gas formation and reduce rumen bypass. When shifting from a pen to a pasture, it is essential to adapt cattle to a continuous grazing system where the intake is gradual and unimpeded. For example, a sudden change from a 6 hour grazing system to a continuous regimen resulted in a rash of bloat cases during the first few days of the new system (Majak, unpublished results). A 3 day adaptation to continuous grazing on grass pasture would be desirable before turning out cattle on alfalfa. As well, turning out onto alfalfa pasture in the afternoon is much less likely to cause bloat than turning out in the morning (Hall and Majak 1995). In summary, pasture management can be used to minimize the risk of bloat and the strategies involve an appreciation of the plant, animal, microbial and environmental factors that contribute to frothy bloat.

\section{Literature Cited}

Berg, B.P., W. Majak, T.A. McAllister, J.W. Hall, D. McCartney, B.E. Coulman, B.P. Goplen, S.N. Acharya, R.M. Tait, and K.J. Cheng. 2000. Bloat in cattle grazing alfalfa cultivars selected for a low initial rate of digestion: A review. Can. J. Plant Sci. 80:493-502.

Berg, B.P. , T.A. McAllister, S.N. Acharya, W. Majak, J.W. Hall, R.M. Tait, and K.-J. Cheng. 1995. Influence of maturity and cultivar of alfalfa on the initial rate of ruminal digestion. Abstr. J. Anim. Sci. 73 (Suppl 1):340.

Goplen, B.P., R.E. Howarth, and G.L. Lees. 1993. Selection of alfalfa for a lower initial rate of digestion and corresponding changes in epidermal and mesophyll cell wall thickness. Can. J. Plant Sci. 73:111-122.

Hall, J.W. and W. Majak. 1995. Effect of time of grazing or cutting and feeding on the incidence of alfalfa bloat in cattle. Can. J. Anim. Sci. 75:271-273.

Hall, J.W. and W. Majak. 1991. Relationship of weather and plant factors to alfalfa bloat in autumn. Can. J. Anim. Sci. 71:861-866.

Hall, J.W., W. Majak, R.J. Williams, and R.E. Howarth. 1984. Effect of daily weather conditions on bloat in cattle fed fresh alfalfa. Can. J. Anim. Sci. 64:943-950.

Hall, J.W., W. Majak, T.A. McAllister, and J.K. Merrill. 2001. Efficacy of Rumensin controlled release capsule for the control of alfalfa bloat in cattle. Can. J. Anim. Sci. (in press).

Harris, L.E., L.C. Kearl, and P.V. Fonnesbeck. 1981. A rationale for naming feeds. Bulletin 501. Inter. Feedstuffs Inst., Utah Agr. Res. Sta., Utah State Univ., Logan, Ut.

Howarth, R.E., K.-J. Cheng, W. Majak, and J.W. Costerton. 1986. Ruminant bloat, p. 516-527. In: L.P. Milligan, W.L. Grovum, and A. Dobson (eds.), Control of digestion and metabolism in ruminants. Prentice-Hall, Englewood Cliffs, N.J.

Koupai-Abyazani, M.R., J. McCallum, A.D. Muir, B.A. Bohm, G.H.N. Towers, and M.Y. Gruber. 1993. Developmental changes in the composition of proanthocyanidins from leaves of sainfoin (Onobrychis viciifolia) as determined by HPLC analysis. J. Agr. Food Chem. 41:1066-1070.
Majak, W., J.W. Hall, and W.P. McCaughey. 1995. Pasture management strategies for reducing the risk of legume bloat in cattle. J. Anim. Sci. 73:1493-1498.

Majak, W., B. Berg, T. McAllister, J.W. Hall, D. McCartney, K.-J. Cheng, and B. Coulman. 1999. Bloat in cattle fed AC Grazeland selected for a low initial rate of digestion. Abstr. Can. J. Plant Sci. 79:118-119.

McMahon, L.R., W. Majak, T.A. McAllister, J.W. Hall, G.A. Jones, J.D. Popp, and K.J. Cheng. 1999. Effect of sainfoin on in vitro digestion of fresh alfalfa and bloat in steers. Can. J. Anim. Sci. 79:203-212.

Makoni, N.F., J.A. Shelford, S. Nakai, L.J. Fisher, and W. Majak. 1993. Characterization of protein fractions in fresh, wilted and ensiled alfalfa. J. Dairy Sci. 76:1934-1944.

Merrill, J.K. and L.A. Stobbs. 1993. The effect of the monensin controlled release capsule on the incidence and severity of bloat and average daily gain in animals grazing legumes. Abstr. J. Anim. Sci. 71 (Suppl. 1): 181 .

Stanford, K., Y. Wang, B.P. Berg, W. Majak, D.H. McCartney, V. Baron, and T.A. McAllister. 2001. Effects of alcohol ethoxylate and pluronic detergents on the development of pasture bloat in cattle and sheep. J. Diary Sci. 84:167-176.

Thompson, D.J., B.M. Brooke, G.J. Garland, J.W. Hall, and W. Majak. 2000. Effect of stage of growth of alfalfa on the incidence of bloat in cattle. Can. J. Anim. Sci. 80:725-727. 